\title{
RANCANG BANGUN PEMBANGKIT HYBRID TENAGA ANGIN DAN SURYA DENGAN PENGGERAK OTOMATIS PADA PANEL SURYA
}

\author{
Diana Hidayanti $^{(1)}$, Galih Dewangga ${ }^{(2)}$, Prakash Yoreniko M. ${ }^{(3)}$, Ineke Sarita ${ }^{(4)}$, F. Gatot \\ Sumarno ${ }^{(5)}$, Wiwik Purwati W(6) \\ Jurusan Teknik Mesin Politeknik Negeri Semarang \\ Jl. Prof H. Sudarto, SH., Tembalang, Kotak Pos 6199/SMS, Semarang 50329 Telp. 7473417, 7499585
}

(Hunting), Fax.7472396

\begin{abstract}
Abstrak
PLTH adalah pembangkit listrik yang menggunakan sumber tenaga angin dan surya yang saling melengkapi menyesuaikan cuaca. Tujuan penelitian adalah membuat alat untuk mengetahui efisiensi apabila PLTB dan PLTS digabungkan atau yang biasa disebut Pembangkit Hybrid. Mengkaji secara eksperimental kinerja Pembangkit hybrid dengan pemasangan mikrokontroller untuk penggerak panel surya. Hasil dari pengujian yaitu penggunaan PLTH menghasilkan efisiensi yang lebih baik dibanding penggunaan PLTB maupun PLTS yang digunakan secara terpisah. Berdasarkan hasil pengujian pembangkit hybrid dengan pemberian kecepatan angin yang semakin besar nilainya maka efisiensi yang didapatkan semakin kecil dan dengan dipasangnya mikrokontroller pada panel surya, panel surya dapat menangkap energi matahari secara optimal. Semakin besar beban yang diberikan maka semakin besar efisiensi yang didapatkan.
\end{abstract}

Kata kunci :"tenaga angin", "tenaga surya", "penggerak otomatis"

\section{Pendahuluan}

Pembangkit Listrik Tenaga Hybrid (PLTH) merupakan pembangkit listrik yang terdiri dari 2 atau lebih pembangkit dengan sumber energi yang berbeda. Misalnya seperti Pembangkit Listrik Tenaga Surya (PLTS) yang dipadu dengan Pembangkit Listrik Tenaga Bayu/Angin (PLTB) atau disebut Hybrid PV-Bayu. Fungsinya salah satunya yaitu apabila langit mendung dan matahari lenyap pada siang hari, maka pembangkit listrik akan digerakkan oleh turbin angin sebaliknya ketika angin berhembus pelan dan matahari lagi terik maka pembangkit listrik akan digerakkan oleh panel surya. Akan tetapi, ketika matahari lagi terik dan angin berhembus kencang maka pembangkit listrik akan digerakkan oleh panel surya dan turbin angin. Namun pada saat ini kebanyakan dari pemasangan panel surya masih diletakkan hanya menghadap ke satu arah, ini mengakibatkan proses penyerapan energi yang dilakukan oleh panel surya hanya berlangsung saat matahari tepat berada di posisi panel surya diletakkan. Agar pemanfaatan dari panel surya dapat dimaksimalkan, maka dibuatlah sebuah sistem yang mampu untuk mendapatkan energi matahari secara penuh, yaitu dengan memasang panel surya dapat terus menghadap kearah matahari. Sistem ini menggunakan mikrokontroller yang dapat mendeteksi pancaran sinar matahari paling optimal.

\section{TINJAUANPUSTAKA \\ 2.1 PengertianPLTH}

Pembangkit listrik tenaga hybrid merupakan gabungan atau integrasi antara beberapa jenis pembangkit listrik yaitu pembangkit listrik berbasis energi terbarukan. 


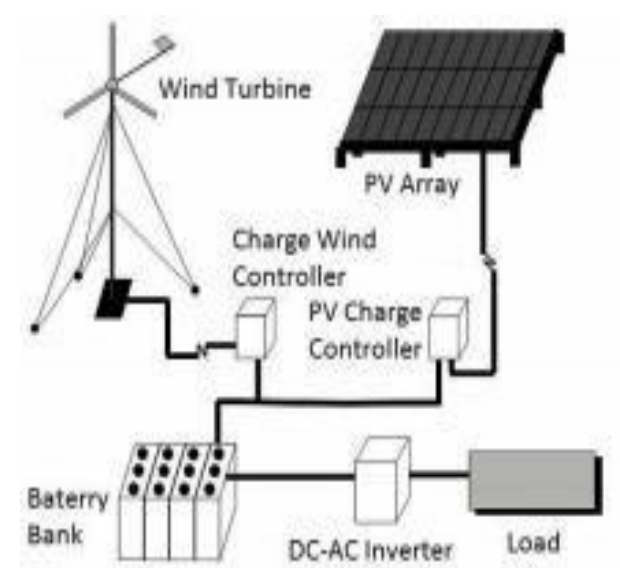

Gambar 2.1 Konfigurasi Pembangkit Listrik Tenaga Hybrid (Surya-Bayu)

(sumber : A. Susandi : 2006)

Tujuan pengembangan teknologi hybrid ini diantaranya untuk mendapatkan daya guna optimal dengan memadukan kelebihan-kelebihan dari dua atau lebih jenis sistem pembangkit tenaga yang bekerja secara terpadu sebagai suatu sistem yang kompak. Sistem-sistem yang mendukung Pembangkit Listrik Tenaga Hybrid adalah sistem sel surya, sistem konversi energi, sistem baterai, sistem inverter, dan sistem kontrol. (Teuku, Suriadi, dan Halid :2018)

\subsection{PengertianPLTB}

Pembangkit listrik tenaga bayu merupakan pembangkit energi listrik yang mengubah energi kinetik angin menjadi energi mekanik oleh turbin dan diubah lagi menjadi energi listrik oleh generator dengan memanfaatkan kecepatan angin yang menggerakkan turbin.

\subsection{PengertianPLTS}

Pembangkit listrik tenaga surya merupakan sebuah teknologi pembangkit listrik yang mengkonversi energi foton dari radiasi atahari menjadi energi listrik.

\subsection{Sistem Pembangkit Hybrid dengan Arduino}

Mikrokontroller adalah sistem mikroprosesor lengkap yang terkandung di dalam sebuah chip. Komponen Pembangkit Tenaga Hybrid Dengan Mikrokontroller adalah sebagai berikut:

1. Arduino Uno

2. Motor Servo

3. Driver Motor

4. Baterai

5. Inverter 


\section{KEGIATAN PELAKSANAAN}

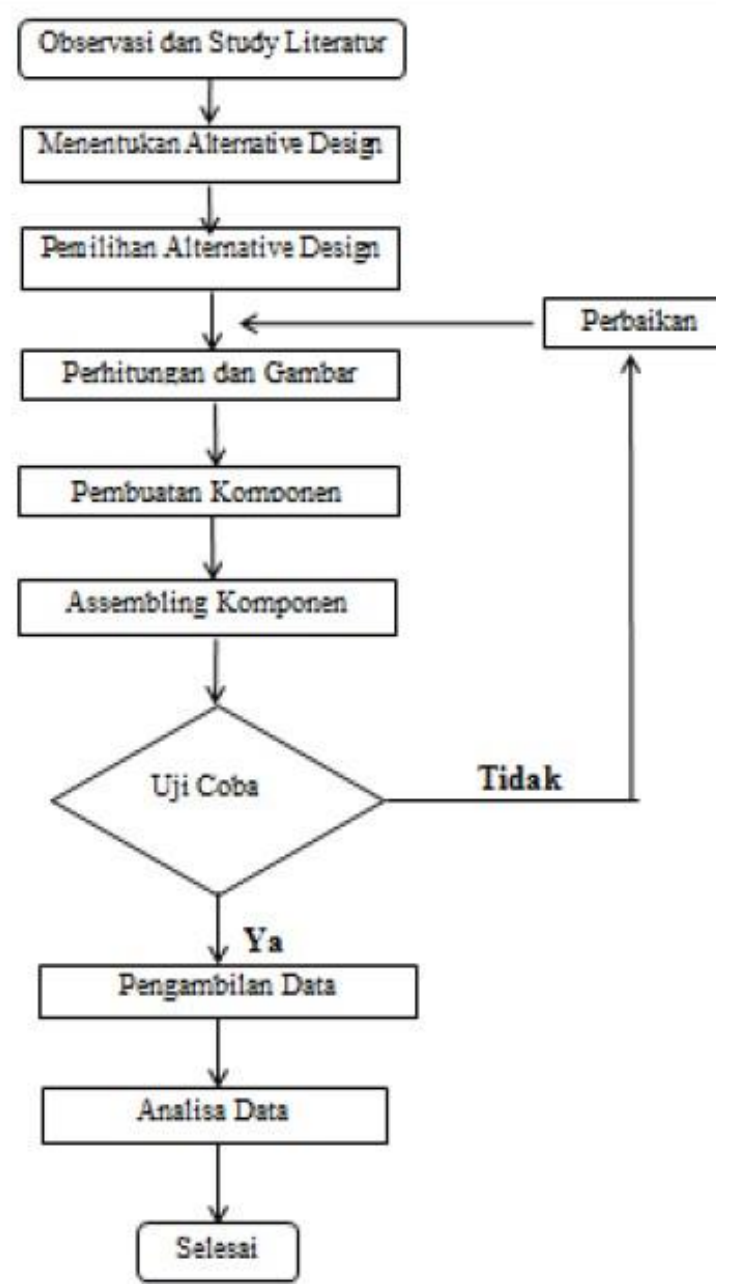

\subsection{Prosedur Pengambilan Data}

Pengujian yang dilakukan meliputi uji guna mendapatkan nilai efisiensi dari Pembangkit Listrik Tenaga Hybrid. Pengujian tersebut menggunakan variasi kecepatan angin, waktu, dan beban. Variasi kecepatan angin didapat dengan variasi jarak blower dari turbin angin.

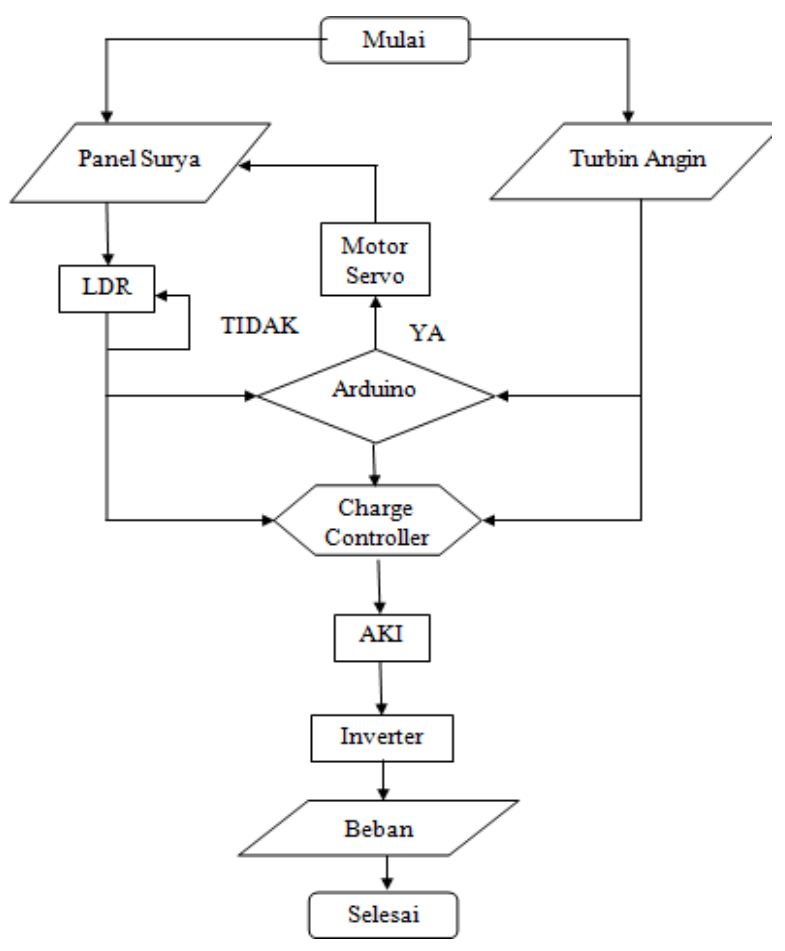

a. Parameter yang Diukur dalam Pengujian

Parameter-parameter yang diukur dalam pengujian ini meliputi kecepatan angin bebas $(\mathrm{m} / \mathrm{s})$ yang akan digunakan memutar sudu turbin dengan menggunakan Anemometer, kecepatan angin didepan sudu dengan menggunakan anemometer, diameter sapuan sudu (m), putaran poros turbin (rpm) yang terbaca dengan menggunakan tachometer untuk mengetahui karakteristik turbin, massa jenis udara $(\mathrm{kg} / \mathrm{m} 3)$ dengan menggunakan Hygrometer, torsi yang dapat dicari dengan mengukur gaya angkat turbin dengan menggunakan alat ukur neraca pegas. Sementara itu, data-data tersebut digunakan untuk menghitung daya mekanik (Watt), daya kinetik (Watt), dan efisiensi (\%). Parameter yang ditentukan dan yang merupakan variable dalam pengujian ini adalah kecepatan angin pada rotor turbin yang divariasikan yaitu 2,5 $\mathrm{m} / \mathrm{s}, 3 \mathrm{~m} / \mathrm{s}$, dan $5 \mathrm{~m} / \mathrm{s}$. Kemudian data diambil mulai dari jam 8 pagi sampai jam 4 sore dengan jarak waktu yaitu satu jam. Pada setiap pengambilan data dilakukan juga pengujian dengan variasi beban yaitu 15 Watt, 19 Watt, 23 Watt, dan 33 Watt. Semua data tersebut dibuat dalam bentuk 
tabel dan selanjutnya dibuat grafik karakteristik sehingga dapat dijadikan sebagai bahan pembahasan serta analisis.

\section{b. Langkah Pengujian}

Langkah-langkah yang dilakukan dalam proses pengujian dapat dijelaskan sebagai berikut:

1. Mempersiapkan semua peralatan uji yang akan digunakan baik sebagai komponen pendukung dan pengukuran seperti blower, Anemometer, Tachometer, Hygrometer, multimeter, Amperemeter, dan Solarimeter.

2. Merangkai Amperemeter dan multimeter pada rangkaian.

3. Mengukur intensitas cahaya yang diukur dengan Hygrometer.

4. Mengukur $\mathrm{RH}$ dengan menggunakan alat ukur Solarimeter.

5. Meng-on-kan tombol pada box panel dan inverter.

6. Mengatur jarak blower dengan turbin untuk mendapatkan kecepatan angin yang telah ditentukan yang diukur menggunakan Anemometer.

7. Meng-On-kan blower.

8. Memulai dengan beban nol pada pengujian awal.

9. Mengukur kecepatan angin didepan turbin $2,5 \mathrm{~m} / \mathrm{s}$

10. Mencatat hasil dari kecepatan angin yang terbaca pada Anemometer.

11. Mencatat hasil dari tegangan dan arus masukan dari panel surya dan turbin.

12. Mencatat tegangan dan arus pada aki.

13. Mencatat arus dan tegangan keluaran.

14. Menambah beban dengan cara mengerem menghidupkan lampu.

15. Mengukur kembali tegangan dan arus masukan maupun keluaran.

16. Mengulangi langkah penambahan beban sampai 23 Watt.

17. Mengulangi langkah 3 sampai dengan langkah 16 untuk setiap variasi kecepatan angin sampai dengan $5 \mathrm{~m} / \mathrm{s}$.

18. Mengambil data dengan jarak waktu satu jam mulai dari pukul 08.00 WIB sampai dengan pukul 16.00 WIB.
19. Merapikan peralatan setelah selesai pengujian.

20. Mengolah data, mencatat hasil dalam tabel, dan membuat dalam bentuk kurva.

\subsection{Tahap Pengolahan dan Analisis Hasil Pengujian \\ 3.5.1 Pengolahan Data}

Pengolahan data dilakukan setelah tahap pengambilan data selesai. Tahap pengolahan data menggunakan persamaan - persamaan sebagai berikut :

\section{a. Pembangkit Listrik Tenaga Surya}

Kinerja sel photovoltaic ini juga mempunyai efisiensi, dimana untuk efisiensi dari sel photovoltaic ini dirumuskan berdasarkan Hukum Thermodinamika II sebagai berikut:

$$
\eta \text { PLTS }=\frac{\mathrm{Im} \cdot \mathrm{Vm}}{\text { Pi } \cdot \mathrm{a}} .
$$

(David L. Pulfrey, PH. D : 1978: 70)

Keterangan :

$\mathrm{Im}=$ arus maksimum $(\mathrm{A})$

$\mathrm{Vm}=$ tegangan maksimum (volt)

$\mathrm{Pi}=$ intensitas radiasi matahari $\left(\mathrm{W} / \mathrm{m}^{2}\right)$

$\mathrm{a}=$ luas penampang panels surya $\left(\mathrm{m}^{2}\right)$

$$
\delta=23,45 \sin \left(360 \frac{284+\mathrm{n}}{365}\right) \ldots \ldots
$$

(Prof. Wiranto Arismunandar. 1995 : 28)

Keterangan :

$\mathrm{n}=$ hari dari tahun yang bersangkutan .

\section{b. Pembangkit Listrik Tenaga Angin}

Energi angin dilihat dari energi kecepatan aliran angin, dapat dituliskan dalam bentuk persamaan energi kinetic berdasarkan Hukum Kekekalan Energi yaitu sebagai berikut:

$$
\mathrm{Ek}=\frac{1}{2} \cdot \mathrm{m} \cdot \mathrm{v}^{2} \ldots \ldots \ldots \ldots \ldots \ldots \ldots \ldots
$$

(Eric Hau. 2006 : 81)

Keterangan :

$\mathrm{m}=$ massa angin yang mengalir $(\mathrm{Kg})$

$\mathrm{v}=$ kecepatan $\operatorname{angin}(\mathrm{m} / \mathrm{s})$ 
Energi kinetik angin inilah yang diekstrak sudu turbin angin untuk diubah menjadi energi mekanis. Laju aliran massa udara yang mengalir pada suatu penampang $\mathrm{A}$ dengan kecepatan $\mathrm{v}$, maka daya kinetis dapat dihitung dengan menggunakan rumus berdasarkan Hukum Kekekalan Energi yaitu sebagai berikut :

$$
\mathrm{Pk}=\frac{1}{2} \cdot \rho \cdot \mathrm{A} \cdot \mathrm{v}^{3} \text {. }
$$

(Eric Hau. 2006 : 82)

Keterangan :

$\mathrm{Pk}=$ daya kinetik, $(\mathrm{W})$

$\rho=$ massa jenis udara, $\left(\mathrm{Kg} / \mathrm{m}^{3}\right)$

$\mathrm{A}=$ luas sapuan blade turbin, $\left(\mathrm{m}^{2}\right)$

$\mathrm{v}=$ kecepatan angin, $(\mathrm{m} / \mathrm{s})$

Tegangan yang dibangkitkan pada pembangkit lisrik tenaga angin ini berupa tegangan DC, sehingga untuk daya outputnya dapat dihitung berdasarkan Hukum Kekekalan Energi yaitu dengan rumus sebagai berikut:

Pout angin $=$ Va. Ia

(Eric Hau. 2006 : 82)

Keterangan :

Pout angin = daya keluar generator DC (W)

$\mathrm{Va}=$ tegangan keluar generator $\mathrm{DC}(\mathrm{V})$

$\mathrm{Ia}=$ arus keluar generator DC (A)

Menghitung efisiensi berdasarkan Hukum Thermodinamika II menggunakan rumus sebagai berikut:

$$
\begin{aligned}
& \text { nPLTB } \\
& =\frac{\text { Poutangin }}{\mathrm{Pk}} .100 \%
\end{aligned}
$$

(Eric Hau. 2006 : 82)

\section{c. Pembangkit Listrik Tenaga Hybrid}

Pada perangkat ini juga dilengkapi dengan inverter yang berfungsi untuk mengubah tegangan DC menjadi AC. Sehingga ini memungkinkan untuk dioperasikan dalam beban AC. Daya beban atau daya keluaran inverter ini diperoleh dari perkalian antara tegangan dan arus, yang dirumuskan berdasarkan Hukum Kekekalan Energi sebagai berikut : Pbeban $=\mathrm{Vb} \cdot \mathrm{Ib} \cdot \cos \varphi$

(Eric Hau. 2006 : 82)

Keterangan :

Pbeban = daya pada beban $(\mathrm{W})$

$\mathrm{Vb}=$ tegangan beban $(\mathrm{V})$

$\mathrm{Ib}=\operatorname{arus}$ beban $(\mathrm{A})$

$\cos \varphi=$ faktor daya

Sistem PLTH ini dengan demikian dapat dihitung nilai efisiensinya, yang dirumuskan berdasarkan Hukum Thermodinamika II yaitu sebagai berikut : nPLTB $=$ $\frac{\text { Pbeban }}{\text { Pk+E }} .100 \%$ (3.8)(Eric Hau. $2006: 82$ )

\section{HASIL PRODUK DAN ANALISA DATA}

\subsection{Data Hasil Pengujian}

Data hasil pengujian diperoleh dari pengujian yang telah dilakukan di Laboratorium Teknik Konversi Energi dapat dilihat pada Tabel 4.1. Data yang diambil merupakan data yang dibutuhkan dalam menganalisis efisiensi PLTH dengan penggerak otomatis pada panel surya. Data tersebut antara lain kecepatanangin, tegangan, arus, relative humidity, intensitas matahari, sudut matahari. Berikut adalah salah satu tabel data hasil pengujian PLTH. 
Tabel 4.1 Data hasil pengujian dengan kecepatan angin $2,5 \mathrm{~m} / \mathrm{s}$ pada beban $15 \mathrm{Watt}$

\begin{tabular}{|c|c|c|c|c|c|c|c|c|}
\hline \multirow{2}{*}{ Pukul } & \multicolumn{2}{|c|}{ Turbin Angin } & \multicolumn{2}{c|}{ Panel Surya } & \multicolumn{2}{c|}{ Aki } & \multicolumn{2}{c|}{ Beban } \\
\cline { 2 - 8 }$(\mathrm{V})$ & $\begin{array}{c}\text { Tegangan } \\
(\mathrm{A})\end{array}$ & $\begin{array}{c}\text { Arus } \\
(\mathrm{V})\end{array}$ & $\begin{array}{c}\text { Tegangan } \\
(\mathrm{A})\end{array}$ & $\begin{array}{c}\text { Arus } \\
(\mathrm{V})\end{array}$ & $\begin{array}{c}\text { Tegangan } \\
(\mathrm{A})\end{array}$ & $\begin{array}{c}\text { Arus } \\
(\mathrm{V})\end{array}$ & $\begin{array}{c}\text { Tegangan } \\
(\mathrm{A})\end{array}$ & \begin{tabular}{c} 
Arus \\
\hline 08.00
\end{tabular} \\
0,7 & 0,038 & 15,4 & 0,31 & 12,4 & 0,01 & 217 & 0,05 \\
\hline 09.00 & 0,7 & 0,038 & 16,8 & 0,35 & 12,6 & 0,01 & 217 & 0,05 \\
\hline 10.00 & 0,7 & 0,038 & 16,9 & 0,4 & 12,3 & 0,01 & 218 & 0,05 \\
\hline 11.00 & 0,7 & 0,038 & 16,9 & 0,43 & 12,4 & 0,01 & 218 & 0,05 \\
\hline 12.00 & 0,7 & 0,038 & 16,9 & 0,5 & 12,4 & 0,01 & 217 & 0,05 \\
\hline 13.00 & 0,7 & 0,038 & 16,8 & 0,5 & 12,4 & 0,01 & 217 & 0,05 \\
\hline 14.00 & 0,7 & 0,038 & 16,9 & 0,49 & 12,6 & 0,01 & 217 & 0,05 \\
\hline 15.00 & 0,7 & 0,038 & 17 & 0,45 & 12,4 & 0,02 & 217 & 0,05 \\
\hline 16.00 & 0,7 & 0,038 & 16,8 & 0,4 & 12,3 & 0,02 & 217 & 0,05 \\
\hline
\end{tabular}

Tabel 4.2Data tambahan hasil pengujian dengan kecepatan angin $2,5 \mathrm{~m} / \mathrm{s}$ pada beban $15 \mathrm{Watt}$

\begin{tabular}{|c|c|c|c|}
\hline Pukul & Intensitas matahari $\left(\frac{w}{m^{2}}\right)$ & RH $(\%)$ & Suhu $\left({ }^{\circ} \mathrm{C}\right)$ \\
\hline 08.00 & 906 & 55 & 29,2 \\
\hline 09.00 & 907 & 52 & 29,2 \\
\hline 10.00 & 907 & 40 & 34,6 \\
\hline 11.00 & 1024 & 45,7 & 35 \\
\hline 12.00 & 1092 & 45,7 & 37 \\
\hline 13.00 & 1089 & 37 & 37 \\
\hline 14.00 & 947 & 35 & 36,3 \\
\hline 15.00 & 886 & 33 & 33,6 \\
\hline 16.00 & 880 & 33 & 33 \\
\hline
\end{tabular}

\subsection{Perhitungan Data Pengujian}

Tabel 4.3. Data Hasil Perhitungan

\begin{tabular}{|c|c|c|c|c|c|c|c|}
\hline Pukul & $\begin{array}{c}\rho_{\text {udara }} \\
\left(\begin{array}{c}k g \\
m^{3}\end{array}\right.\end{array}$ & Pk (W) & E (W) & $\begin{array}{c}\text { Poutput } \\
(W)\end{array}$ & $\begin{array}{c}\text { Efisiensi } \\
\text { PLTH (\%) }\end{array}$ & $\begin{array}{c}\text { Efisiensi } \\
\text { PLTB (\%) }\end{array}$ & $\begin{array}{c}\text { Efisiensi } \\
\text { PLTS (\%) }\end{array}$ \\
\hline 08.00 & 1,15766 & 5,7883 & 43,77 & 10,85 & 21,89311 & 0,459548 & 10,90685 \\
\hline 09.00 & 1,15819 & 5,791 & 43,82 & 10,85 & 21,87062 & 0,4593374 & 13,41884 \\
\hline
\end{tabular}




\begin{tabular}{|c|c|c|c|c|c|c|c|}
\hline 10.00 & 1,13747 & 5,6874 & 43,82 & 10,9 & 22,01738 & 0,4677046 & 15,4271 \\
\hline 11.00 & 1,13441 & 5,6721 & 49,47 & 10,9 & 19,7666 & 0,4689662 & 14,68927 \\
\hline 12.00 & 1,12583 & 5,6292 & 52,76 & 10,85 & 18,58327 & 0,4725403 & 16,01692 \\
\hline 13.00 & 1,12815 & 5,6408 & 52,61 & 10,85 & 18,6258 & 0,4715685 & 15,96601 \\
\hline 14.00 & 1,13158 & 5,6579 & 45,75 & 10,85 & 21,1051 & 0,4701391 & 18,09997 \\
\hline 15.00 & 1,14325 & 5,7163 & 42,8 & 10,85 & 22,3616 & 0,46534 & 17,87198 \\
\hline 16.00 & 1,1457 & 5,7287 & 42,51 & 10,85 & 22,4909 & 0,464328 & 15,8063 \\
\hline
\end{tabular}

Data Tabel 4.1 selanjutnya dihitung dengan persamaan pada bab 3 untuk mendapatkan Daya Kinetik Turbin Angin $\left(\mathrm{P}_{\text {kin }}\right)$, Daya Masukan pada PanelSurya(E), Daya Output PLTH , Efisiensi PLTB, Efisiensi PLTS , dan Efisiensi PLTH.

4.3 Karakteristik dan Analisa Data 4.3.1 Karateristik Waktu terhadap Efisiensi

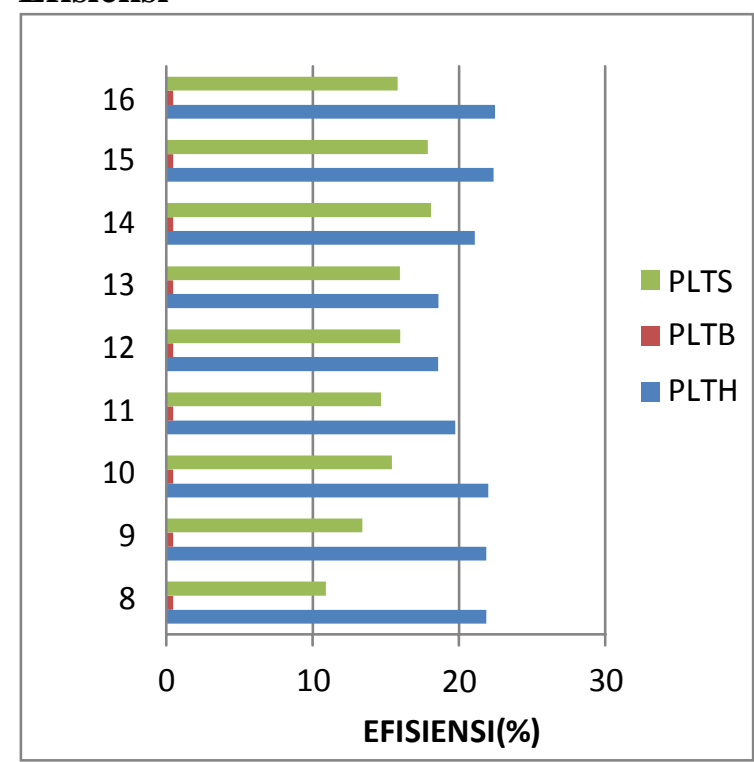

Gambar 4.1 Grafik waktu terhadap efisiensi

Grafik 4.1 hubungan efisiensi terhadap waktu pada kecepatan $2,5 \mathrm{~m} / \mathrm{s}$ ketika diberi beban 15 Watt menunjukkan perbandingan antara penggunaan PLTB, PLTS, dan PLTH. Grafik 4.2 menggambarkan bahwa dalam penggunaan PLTH ini lebih menghasilkan efisiensi yang bagus dibanding dengan penggunaan
PLTB maupun PLTS yang digunakan secara terpisah.

\subsubsection{Karakteristik Efisiensi PLTH terhadap Beban}

Untuk mengetahui perbandingan efisiensi antara PLTB, PLTS, dan PLTH dibuat grafik hubungan efisiensi terhadap beban seperti berikut :

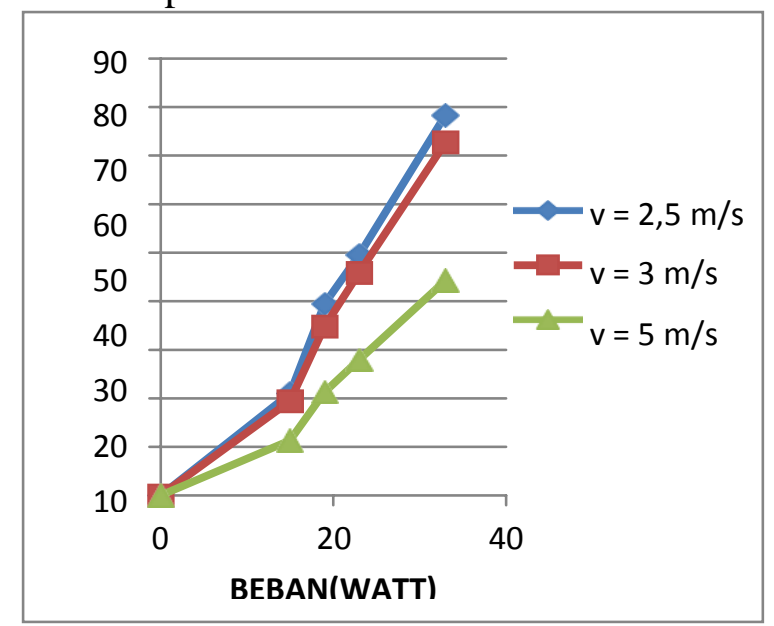

Gambar 4.2 Grafik efisiensi fungsi beban

Grafik efisiensi PLTH fungsi beban, pada kecepatan $2,5 \mathrm{~m} / \mathrm{s}$ ketika diberi beban 15 Watt (beban pertama) maka efisiensi PLTH adalah 20,968\%, setelah itu diberi beban 19 Watt (beban kedua) maka efisiensi PLTH adalah 39,48 \%, selanjutnya diberi beban 23 Watt (beban ketiga) maka efisiensi PLTH yang didapatkan adalah 49,57\%, dan pada saat beban 33 Watt (beban keempat) maka efisiensi PLTH adalah 78,39\%. Fluks magnet yang diberikan oleh kutub-kutub utama dari sebuah generator tanpa beban disebut disebut fluks medan utama. 
Pada kecepatan $3 \mathrm{~m} / \mathrm{s}$ ketika diberi beban 15 Watt (beban pertama) maka efisiensi PLTH adalah 19,41 \%, setelah itu diberi beban 19 Watt (beban kedua) maka efisiensi PLTH adalah 34,83 \%, selanjutnya diberi beban 23 Watt (beban ketiga) maka efisiensi PLTH yang didapatkan adalah $45,83 \%$, dan pada saat beban 33 Watt (beban keempat) maka efisiensi PLTH adalah 27,96\%.

Pada kecepatan $5 \mathrm{~m} / \mathrm{s}$ ketika diberi beban 15 Watt (beban pertama) maka efisiensi PLTH adalah 11,27 \%, setelah itu diberi beban 19 Watt (beban kedua) maka efisiensi PLTH adalah 21,64 \%, selanjutnya diberi beban 23 Watt (beban ketiga) maka efisiensi PLTH yang didapatkan adalah 27,96\%, dan pada saat beban 33 Watt (beban keempat) maka efisiensi PLTH adalah 44,29\%.

Fluks ini memotong lilitan jangkar yang mengakibatkan timbulnya tegangan induksi. Dengan pemberian beban maka timbul arus jangkar, arus jangkar menyebabkan timbulnya fluks pada penghantar jangkar yang biasa disebut dengan fluks medan jangkar. Munculnya medan jangkar akan memperlemah medan utama. Interaksi ini dinamakan reaksi jangkar. Sehingga apabila diberi beban maka tegangan akan turun dan arus akan besar, dimana efisiensi berbanding lurus dengan arus maka semakin beban bertambah efisiensi akan bernilai besar.

\section{PENUTUP}

\subsection{Kesimpulan}

Berdasarkan data hasil pengujian dan analisis, maka dapat disimpulkan sebagai berikut:

1. PLTH dengan turbin angin sudu tipe flat berlapis memiliki 3 buah sudu dengan sudut kemiringan antar sudunya $8^{\circ}$. Panel surya tipe polycrystalline dengan kapasitas 10 WP, dimensi panel surya ,panjang : $0,264 \mathrm{~m}$; lebar $0,183 \mathrm{~m}$; tinggi $0,015 \quad \mathrm{~m}$. Pemasangan mikrokontroller pada panel surya, dan inverter dengan kapasitas 150 Watt.

2. Penggunaan PLTH menghasilkan efisiensi yang lebih baik dibanding penggunaan PLTB maupun PLTS yang digunakan secara terpisah.

3. Hasil uji karakteristik pada masingmasing beban didapatkan efisiensi tertinggi pada kecepatan $2,5 \mathrm{~m} / \mathrm{s}$. Efisensi pada beban 15 Watt sebesar 20,968\%, beban 19 Watt sebesar $39,48 \%$, beban 23 Watt sebesar 49,57\%, dan pada beban 33 Watt sebesar $78,39 \%$. Sedangkan efisiensi terendah didapatkan pada kecepatan $5 \mathrm{~m} / \mathrm{s}$. Efisiensi pada beban 15 Watt sebesar 11,27\%, beban 19 Watt sebesar 21,64\%, beban 23 Watt sebesar 27,96\%, beban 33 Watt sebesar 44,29\%.

4. Semakin besar beban yang diberikan maka semakin besar efisiensi yang didapatkan.

5. Semakin besar kecepatan angin maka semakin kecil nilai efisiensi yang didapatkan.

6. Pemasangan mikrokontroller pada panel surya dapat menangkap panas matahari secara optimal.

\subsection{Saran}

Pengerjaan dan penyelesaian penelitian ini tentu tidak lepas dari berbagai macam kekurangan dan kelemahan. Untuk memperbaiki kekurangan tersebut maka saran yang diberikan adalah PLTH yang dibuat adalah rancangan pertama, perlu adanya pengembangan dalam pemilihan kapasitas panel surya dan jenis turbin yang digunakan agar dapat mengisi aki dengan cepat.

\section{DAFTAR PUSTAKA}

- $\quad$ Effendi, Asnal,dan Arfita Yuana.2016. PEMBANGKIT LISTRIK SISTEM HIBRIDA SEL SURYA DENGAN ENERGI ANGIN, Padang: Teknik Elektro Fakultas Teknologi Padang 
- Girsang , Melyana,dan Pramana Rozeff.2014.PROTOTIPE HIBRID PANEL SURYA DAN TURBIN ANGIN, Riau: Jurusan Teknik Elektro Fakultas Teknik, Universitas Maritim Raja Ali Haji

- Hayu,Teuku,Syaufi,dkk.2018. Studi Potensi Pembangkit Listrik Tenaga Hybrid (Surya-Bayu) di Banda Aceh Menggunakan Metode Jaringan Syaraf Tiruan. Aceh: Jurusan Teknik Elektro dan Komputer, Fakultas Teknik, Universitas Syiah Kuala

- Hendrayana, 1, Februari 2017. Simulasi Sistem Hibrid Pembangkit Energi Surya, Angin, dan Generator Untuk Mengoptimalkan Pemanfaatan Daya Energi. Darussalam Banda Aceh: Magister Teknik Elektro Universitas Syiah Kuala

- Kusuma, yudhy,dkk.2015. Rancang Bangun Penggerak Otomatis Panel Surya Menggunakan Sensor Photodioda Berbasis Mikrokontroller
Atmega 16, Lampung: Jurusan Teknik Elektro Universitas Lampung

- Ramadhan, Andrian,dkk.2017.PEMANFAATAN ENERGI SURYA MATAHARI PADA SOLAR CELL UNTUK PENGISIAN ACCUMULATOR (ACCU) BERBASIS MIKROKONTROLLER ARDUINO UNO. Semarang: Teknik Elektro, Universitas Diponegoro Semarang

- Rubianto, Sulis.2017. ANALISIS KINERJA PENGOPERASIAN PEMBANGKIT LISTRIK TENAGA HYBRID ENERGI ANGIN DAN MATAHARI DENGAN MELALUI BATTERY UNTUK PEMBEBANAN, Semarang: Jurusan Teknik Mesin Politeknik Negeri Semarang Program Studi Teknik Konversi Energi

- Suciatna, Fajar,Ramadhan,dkk.2016. PEMBUATAN TURBIN ANGIN SUDU TIPE FLAT BERLAPIS TIGA, Semarang: Program studi teknik konversi energy. 